\title{
Evaluation of Activities of Marigold Extract on Wound Healing Of Albino Wister Rat
}

\author{
${ }^{1}$ F. N Oguwike, ${ }^{2}$ D. P. M Onubueze and ${ }^{3}$ P. Ughachukwu \\ ${ }^{I}$ Department of physiology, Anambra State University, Anambra State Nigeria. \\ ${ }^{2}$ Department of Community medicine and PHC, Anambra state university teaching hospital Amaku, Awka, \\ Anambra state Nigeria. \\ ${ }^{3}$ Department of Pharmacology Anambra state university teaching hospital Amaku Awka, Anambra state.
}

\begin{abstract}
The activities of Marigold (T.erecta) extract on the wound healing of albino Wister rats have been evaluated. Thirty six male and female rats weighing 150-200g were randomly selected and divided into 4 groups $(A, B, C, D)$. The test rats were fed normal rat feed and water ad libitum in addition to oral administration of $1.0 \mathrm{ml}$ of the petal extract of marigold.

Blood samples were obtained by cardiac puncture of the animals into EDTA bottles for analysis. The initial blood picture of the animals was taken before administration of the extracts to the test rats.

Results showed that Tagete erecta extract increased platelet count, white blood cell count $(p>0.05)$ and shortened the bleeding and clotting times. There was a slight increase in haemoglobin concentration and Packed cell volume.
\end{abstract} the extract.

This shortening in bleeding and clotting times could be due to presence of certain elements present in

Short running title: Marigold, evaluation, wound healing, platelet count, and bleeding time.

\section{Introduction} medical cure.

In the developing countries especially the sub-saharan part of Africa, people mostly depend on herbal

In the Eastern part of Nigeria, traditional medicine has been virtually used in preventing and curing diseases, thereby playing an important role in the health service in the region especially among the low socialeconomic class. These herbs are mostly administered topically as ointment on wounds and abrasion. Extracts of roots, stem bark and leaves of some medicinal plants have been known to have effects against the most dreaded pathogenic organisms like bacteria, fungi, viruses (Russel et al, 1997) and also some others still serve as liver tonic (crescent 2009)

Marigold (Tagetes) is a genius of 56 species (Soule, 1996) of the annual and perennial mostly herbaceous plants in the sunflower family. (Asteraceae or compositae). The genus is native to North and South America, but some species have become naturalized around the world. The cultivated varieties of tagetes are known variously as marigolds; Mexican marigolds (cempasuchil), Africa marigolds (Tagetes erecta) although this species is not native to Africa.

Tagetes species vary in size from 0.1 to $2.2 \mathrm{~m}$ tall. Most species have pinnate green leaves. Blooms are naturally in golden: orange, yellow and white colors, often with maroon highlights.

Marigold has been valued for many centuries for its exceptional healing powers and its particularly remarkable in the treatment of wounds. When used for medicinal purposes it is commonly referred to as calendular and the botanical name is calendula officinalis (Davies, 2002). Only Marigold's flower heads are used medicinally. The bright petals contain powerful natural chemicals that give the herd its amazing healing properties. Marigold is well known as a wound healing, antiseptic and stimulating remedy but in fact Modern herbalists rely upon this plant for a wide-range of uses. It is this reliance on Marigold by modern herbalists that stimulated our curiosity to evaluate the activities of this plant on the haemostatic and healing mechanism of albino rats.

Phytochemical constituents of Marigold indicates the presence of carotenes (pigments resent in their orange colouring), flavonoids, resin, saponin, sterols, triterpenes, bitter glycosides, volatile oils, calcium and alkaloids. Some of the substances, in combination with the high resin content provide Marigold with its powerful anti-inflammatory action. It is a good remedy for inflamed skin, open fresh wounds and for a range of microbial and parasitic infections. The plant also has an estrogenic action, which is probably due to its sterol and saponin content which is why it makes a useful regulator of hormones in the female body. 
Animals:

\section{Materials And Methods}

Albino rats weighing 150-200g of both sexes were randomly selected and their health status maintained at healthy condition. Male and female rats were kept separately for 28 days feeding.

\section{Preparation Of Extracts:}

The bright petals of African marigold (Tagetes erecta) were plucked from herbarium weighing $250 \mathrm{~g}$. They were washed, sundried for 18 days and the dried sample were crushed to powder using a mechanical blender. The powdered petals were stored in a glass bottle with a plastic screw cap and kept in a refrigerator $\left(4^{\circ} \mathrm{C}\right)$, (Edet et al, 2009). The petals were homogenized with distilled water by shaking and kept for 12 hours. The mixture was filtered with Whatman No. 1 filter paper. The filtrates were concentrated to one-tenth $(1 / 10)$ of the original volumes at $38-40^{\circ} \mathrm{c}$ using a rotary evaporator. The aqueous extract was freeze dried yielding a light yellow powder. The powders were resuspended in distilled water before use (Ugochukwu et al, 2003). The extract was administered $1.0 \mathrm{ml}$ orally daily to each of the rats using blunt syringe for 28 days. The control group received clean water instead of the extract.

\section{*Inflicting Fresh Wound On Albino Rats:}

The animals were made to acclimatize to housing condition in animal house for one week and were fed very well. Prior to the commencement of the experiment, the test rats were injected with $0.4 \mathrm{ml}$ of thiopentane injection to anaesthetize them. The area for wound infliction was chosen, preferably on the back. The hairs were shared off with scissors and lancet was used to cut the skin. The wound was in form of square (the length and width of the wound were measured and the result expressed in centimeter. Equal area of wound was given to both the control and the test rats. Measurement was taken on the first day the wound was inflicted.

The control rats were rubbed with normal saline. While the test rats (Male and female) were rubbed with extract of Marigold. The number of days it took for the wound to heal was recorded in the result.

\section{*Toxicity Study $\left(\mathbf{L d}_{50}\right)$}

The $\mathrm{LD}_{50}$ of the extract in albino rat was determined using Lorke's method (1983). Albino rats (180$200 \mathrm{~g}$ ) were fasted overnight for 12 hours and doses of the extract $(10 \mathrm{mg} / \mathrm{kg}, 29 \mathrm{mg} / \mathrm{kg}$ body weight) were administered to fresh groups of rats that served as control received normal saline only. The $\mathrm{LD}_{50}$ for the extract was calculated by geometric mean of the dose killing non of the three rats in the group and dose killing all the animals in the group.

\section{$\mathrm{LD}_{50}=$ Dose killing all animals in the group $\mathrm{x}$ Dose killing none of the animals in the group.}

\section{Methods:}

Haemoglobin estimation was determined by method described by Baker 1985 .

Packed cell volume estimation was done by the simple method of micro-haematocrit centrifugation (Baker 1985).

- The total white blood cell count and platelet count were estimated by visual counting method of Dacie and Lewis.

. Whole blood clotting time and bleeding time were carried out by the method of Dejana et al (1982).

\section{Experimental Design}

Thirty six albino rats divided four groups were used for the study. This was grouped thus Group 1 (Male control rats), Group 2 (female control rats), Group 3 (male test rats) and Group 4 (female test rats). The test rats received $1.0 \mathrm{ml}$ daily of the extract of Marigold added to their normal rat feed.

\section{Collection Of Blood Samples}

$2.0 \mathrm{ml}$ of blood samples were collected from each rat in all the groups by cardiac puncture into EDTA bottles to determine initial blood pictures before feeding them on the extract, another blood samples were again obtained for determining the haematological profile. 


\section{Statistical Analysis}

The result obtained in the study for $\mathrm{Hb}$ estimation, packed cell volume,WBC count, platelet count, Clotting and Bleeding times were represented as Mean and Standard Deviation (Mean \pm S.D) while students' $T$ test was used to compare the result of the control and the test rats.

A P-value of less than $(\mathrm{p}<0.05)$ or equivalent to $(\mathrm{p}=0.05)$ was considered statistically significant.

\section{Results}

Table 1: shows the effect of African Marigold (T. erecta) on duration of healing in albino rats. Wounds healed faster in test rats on T. erecta extracts.

\begin{tabular}{|l|l|l|c|}
\hline Groups & Extract & Days Mean \pm S.D & P-Value \\
\hline A, Control male $(n=9)$ & Placebo & $13 \pm 1.65$ & - \\
\hline B, Control female $(n=9)$ & Placebo & $13 \pm 0.60$ & - \\
\cline { 1 - 2 } Test Groups & T. erecta & $8 \pm 0.5$ & $P<0.05$ \\
\cline { 1 - 2 } C, Male $(n=9)$ & T. erecta & $6 \pm 0.3$ & $P<0.05$ \\
\hline D, Female $(n=9)$ &
\end{tabular}

Table 2: Shows the activities of $\mathrm{T}$. erecta extracts on total white blood cell count, platelet count, haemoglobin concentration and packed cell volume of control and test rats.

\begin{tabular}{|c|c|c|c|c|}
\hline Groups & $\begin{array}{l}\text { WBC count/ } \\
\mathrm{mm}^{3} \times \pm \text { S.D }\end{array}$ & $\begin{array}{l}\text { Platelet count } x \\
10^{6} x \pm \text { S.D }\end{array}$ & $\begin{array}{l}\text { Haemoglobin } \\
\text { conc g/dl } \mathrm{x} \quad \pm- \\
\text { S.D }\end{array}$ & $\begin{array}{l}\text { Packed } \\
\text { volume } \%{ }_{-} \mathrm{x}^{+}- \\
\text {S.D }\end{array}$ \\
\hline $\begin{array}{l}\text { A, Control male } \\
(\mathrm{n}=9)\end{array}$ & $4,150 \pm 400$ & $170 \pm 58$ & $13.8 \pm 4.0$ & $41 \pm 5.0$ \\
\hline $\begin{array}{l}\text { B, Control female } \\
n=9\end{array}$ & $4,800 \pm 210$ & $160 \pm 62$ & $13.0 \pm 6.2$ & $40 \pm 4.3$ \\
\hline Test Group & \multirow[t]{2}{*}{$8,080 \pm 105$} & \multirow[t]{2}{*}{$230 \pm 89$} & \multirow[t]{2}{*}{$14.2 \pm 30$} & \multirow[t]{2}{*}{$43.0 \pm 6.0$} \\
\hline $\begin{array}{l}\mathrm{C} \text {, male } \mathrm{n}=9 \text { after } \\
28 \text { days feeding }\end{array}$ & & & & \\
\hline $\begin{array}{l}\mathrm{D}, \text { female } \mathrm{n}=9 \text { after } \\
28 \text { days feeding }\end{array}$ & $7,200 \pm 230$ & $245 \pm 62$ & $14.0 \pm 2.59$ & $42.0 \pm 7.0$ \\
\hline P.value & $\mathrm{P}<0.05$ & $\mathrm{P}<0.05$ & $\mathrm{P}<0.05$ & $\mathrm{P}<0.05$ \\
\hline
\end{tabular}

Table 3: shows the effects of T.erecta (Marigold) on bleeding and clotting times of albino rats

\begin{tabular}{|l|l|l|}
\hline Groups & $\begin{array}{l}\text { Bleeding time (minutes) } \\
\pm \text { S.D }\end{array}$ & Clotting time (minutes) $\mathrm{x} \pm$ S.D \\
\hline Group A male control $\mathrm{n}=9$ & $4.00 \pm 0.25$ & $3.2 \pm 0.02$ \\
\hline Group B female control $\mathrm{n}=9$ & $4.10 \pm 0.20$ & $3.35 \pm 0.41$ \\
\hline $\begin{array}{l}\text { Test } \mathrm{C} \text { male } \mathrm{n}=9 \text { after } 28 \text { days } \\
\text { of extract feeding }\end{array}$ & $2.05 \pm 0.71$ & $1.32 \pm 0.27$ \\
\hline $\begin{array}{l}\mathrm{D} \text { female } \mathrm{n}=9 \text { after } 28 \text { days of } \\
\text { extract feeding }\end{array}$ & $2.0 \pm 0.34$ & $1.29 \pm 0.15$ \\
\hline $\mathrm{P}$ value & $\mathrm{P}<0.05$ & $\mathrm{P}<0.05$ \\
\hline
\end{tabular}

VIII. Discussion

The activities of marigold (T.erecta) extract on wounds healing of albino wister rats have been evaluated in the study. Many plants extract are usually given in large doses by herbalist to human beings hence acute toxicity using $\mathrm{LD}_{50}$ were carried out before the extract was given to the animals. The result of lethality studies showed that doses used in this study was below the lethal dose and so was considered save to the animals used throughout the period of study.

The extracts of Marigold fastened the healing period of test rats.

$8 \pm 0.5$ days in male and $6 \pm 0.3$ days in female rats (Table 1 ) compared to their corresponding controls. This consistent with the report that Marigold is a remarkable in the treatment of wounds (Davis 2002). It is well known as a wound healing, antiseptic and stimulating remedy. It has also anti- inflammatory and anti-bacterial property.

The antibacterial property is assumed to be due to osmotic effect of high sugar pastes has an osmolarity sufficient to inhibit microbial growth, (Chirife et al, 1983) but when used as a wound contact layer, dilution by wound exudates reduces the osmolarity to a level that ceases to control infection (Herszage et al, 1980). 
The cleaning of infection seen when Marigold extract is applied to a wound may reflect more than just antibacterial properties.

The extract of Marigold slightly increased the haemoglobin concentration and packed cell volume of rats after 28 days of feeding $(\mathrm{P}<0.05)$. This is consistent with the report that (Davies 2002).

The white blood cell counts were increased $(\mathrm{P}<0.05)$ to their glycoside content. The increase in leukocyte count could be physiological as suggested by Penington, 1978. Platelet count was increased $(\mathrm{P}<0.05)$ and the extract shortened the bleeding and clotting times of albino rats thus demonstrating haemostatic activity.

The petals of Marigold indicated a reduction in bleeding and clotting times of albino rats $(\mathrm{P}<0.05)$, (Table 3) and also can stop a bleeding surface and hemorrhage. This could be due to presence of calcium ion and alkaloids. It is observed that calcium ion was a principal active ingredients present in the plasma and bone.

It is free calcium ions that are physiologically active in coagulation mechanism calcium ions are essential for the conversion of prothrombin to thrombin and for the normal action of heart muscle and for neuromuscular conduction. The presence of calcium in the extract of Marigold might have contributed to the shortening of bleeding and clotting times respectively in the albino rats. Calcium ions present in the extract probably act in the intrinsic and extrinsic coagulation mechanism to convert thrombin which in turn converts fibrinogen to fibrin strands (Seegers 1950).

Haemostasis involves in the spontaneous arrest of bleeding from damaged blood vessels and the prevention of tissue death through hemorrhage (Okoli et al, 2007).Vessels and the prevention of tissue death through hemorrhage

\section{References}

[1]. Baker F.J(1985). The full blood count, introduction to medical laboratory technology, Butter worths publication, Woburn London pg 325-328.

[2]. Chirife J, Herszage L, Joseph A, Kohn E.s (1983). In vitro study of bacteria growth inhibition in concentrated sugar solution: Micro biological basis for the use of sugar in treating infected wounds. Anti microbe agent's chemother 1983, 23 (5): 766-73.

[3]. Crescent Bloo. Com (2009). Medicinal action of common plants.

[4]. Dacie J.K and Lewis S.M (1991). Pratical Haematology London. Churchill living stone pp 566.

[5]. Davies J.R, (2002). In dept profile of marigold- calendula officinalis herbs hands he...... http/ www.herbs. Hands healing. Co. UK /single herbs/ marigold. Html.

[6]. Dejana E, Degactano G, (1982). Bleeding time in rats. A comparision of different experimental conditions. Thromb. Haemostat 48:108-111.

[7]. Edet E.E, Akpanabiatu M.L, Eno A.E, Umohi.B Han E.H (2009): Effect of Gongronema latifolium crude leaf extract on some caroliac enzymes of alloxan-induction induced rats. African journal of biochemistry 3(11) 366-369.

[8]. Herszage L, Montemegro J.R, Joseph A.L, accucargranulado commercial. Bol trabsoc Argent Cir 1980, 41 (21-22):315-30.

[9]. Lorke D. (1993). A new approach to pratical acute toxicity testing. Arch toxicol 54: 275-278.

[10]. Okoli C.O, Akah P.A, Okoli A.S (2007). Potentials of leaves of Aspilla Africana(compositae)in wound care: an experimental evaluation.

[11]. Penington D, 1978. Pathological variation in white cell values. Clinical haematology in medical prati e. Blackwell scientific publication osney mend oxford ox2 OE 18 johnson street London pp396.

[12]. Russel B.A, Hardin J.N, Grand L, Traser A(1997), Poisonous plants of north Carolina, caesalphina spp (pride of Barbados). Department of Horticulture science. North Caroline state University http / www.ces . nessy. Edu/dept.

[13]. Seegers W.H(1950). Blood coagulation and the practical significance of recent advanced in knowledge of prothrombin and A.Cglobulin circulation 1:2.

[14]. Soule J.A (1996). Infrageneric systematic of Tagetes pgs 435-443 in compositae: systematic, proceeding of the international compositae conference, Kew 1 .

[15]. Ugochukwu N.H, Babady N.E, Cobourne M, Gasset S.R (2003). The effects of Gongronema latifiolum extract on serum lipid profile and oxidative stress in hepatocytes of diabetic rats. Journal of Bioscience 28(1) 1 -5. 